\title{
ANALISIS TINGKAT EFISIENSI BANK PERSERO DENGAN MENGGUNAKAN DATA ENVELOPMENT ANALYSIS (DEA) \\ (Studi kasus pada Laporan Keuangan Bank Persero yang Terdaftar di Bank Indonesia Periode 2004-2013 )
}

\author{
Tedi Apriadi \\ Universitas Pendidikan Indonesia \\ Dr. H Nugraha \\ Universitas Pendidikan Indonesia
}

\begin{abstract}
ABSTRAK
Penelitian ini bertujuan mengukur tingkat efisiensi bank persero periode tahun 2004-2013 dengan menggunakan metode Data Envelopment Analysis (DEA), dengan softwere BANXIA. Pendekatan yang digunakan dalam memilih input dan output adalah pendekatan intermediasi. Faktor Input yang digunakan adalah aset, deposito dan beban personalia. Faktor output yang digunakan adalah kredit dan pendapatan operasional lainnya. Hasil penelitian diperoleh bahwa (1) penggunaan input aset, deposito dan beban personalia rata-rata meningkat.Dan penggunaan output kredit dan pendapatan operasional lainnya juga rata-rata meningkat.(2) Penggunaan input dan output bank persero dari tahun 2004-2013 dengan menggunakan DEA belum mencapai efisiensi optimum. Model Variable Return To Scale lebih baik dari pada model Constan Return To Scale. (3) Efisiensi skala bank persero dengan metode DEA berada pada tahap Decreasing Return to Scale. Dalam keadaan demikian, dapat diartikan bahwa proporsi penambahan input akan menghasilkan tambahan output yang proporsinya lebih kecil.
\end{abstract}

Kata Kunci : Efisiensi, DEA, Bank Persero.

\section{PENDAHULUAN}

Perkembangan dalam mengukur tingkat kesehatan bank di Indonesia mengalami perubahan yang signifikan. Dari mulai Surat Edaran Bank Indonesia No.26/BPPP/1993 yang diedarkan pada tanggal 18 mei tahun 1993 tentang pengukuran tingkat kesehatan bank dikenal dengan metode CAMEL (Capital adequacy, Quality of productive Asset, Manajemen risk, Earning Liquidity). Metode ini dalam perkembangannya mempunyai kelemahan. Beberapa kelemahan dari metode CAMEL adalah perhitungannyamenggunakan pendekatan yang berbasis rasio yaitu menghitung laba bila pemasukan (return) lebih tinggi dari pengeluaran (cost), Mendasarkan pada pendekatan yang hanya memperhitungkan komponen modal hutang sebagai komponen yang menimbulkan biaya modal.

Indonesia dalam Surat Edarannya N0.6/10/PBI/2004 tentang sistem penilaian tingkat kesehatan bank yaitu CAMELS (Capital Asset Quality, Management, Earning Power, Liquidity, dan Sensitivity to Market Risk). Tidak jauh dengan metode CAMEL hanya adanya penambahan mengenai risiko pasar dalam penilainanya. Pada penilaian CAMELS tidak hanya bersifat kuantitatif namun juga mempertimbangan aspek kualitatif dalam bentuk expert Judgment.

Dikarenakan masih membutuhkan penyempurnaan pada metode CAMELS ini maka Bank Indonesia kembali mengeluarkan Surat Edarannya untuk menghitung tingkat kesehatan bank lebih menspesifikasikan menjadi RGEC (Risk profile, Good Corporate Governance, Earning dan Capital) supaya mudah untuk diingat dan mudah untuk diimplementasikan. Dengan adanya kelemahan dalam menggunakan metode CAMEL, CAMELS, dan RGEC yang bersifat umum maka harus dicarikan solusi dalam menghitung kinerja bank yang efisien. Dengan berkembangannya metode penilaian kesehatan bank dan seiring dengan berkembangnya perbankan di Indonesia maka perlu kiranya untuk diketahui tingkat efisiensi bank.

Perkembangan perbankan di Indonesia relatif tumbuh dengan cepat hal ini dapat tergambar pada Gambar 1.1 di bawah ini dengan indikator penyaluran dana. 


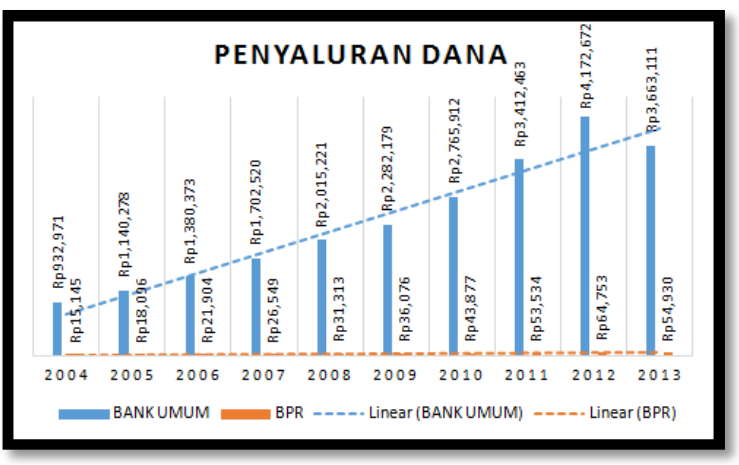

GAMBAR 1.1 PERKEMBANGAN

PENYALURAN DANA BANK UMUM

TAHUN 2004-2013 DALAM MILLIAR RUPIAH

Sumber: Otoritas Jasa Keuangan (data diolah)

Dari Gambar 1.1 memberikan informasi bahwa perkembangan kegiatan usaha perbankan Indonesia dari indikator penyaluran dana tiap tahun mengalami peningkatan baik Bank Umum maupun Bank Perkreditan Rakyat. Trend kenaikan pada bank umum dari tahun 2004 sampai 2013 menunjukan trend yang sangat kuat. Trend kenaikan yang sangat kuat pada indikator penyaluran dana menunjukan bahwa bank dengan fungsi intermediasinya mampu menyalurkan dana dengan cepat. Tentunya adanya penyaluran dana tidak terlepas dari adanya sumber dana berikut gambaran perkembangan sumber dana bank umum tahun 2004 sampai 2013 pada Gambar 1.2 di bawah ini.

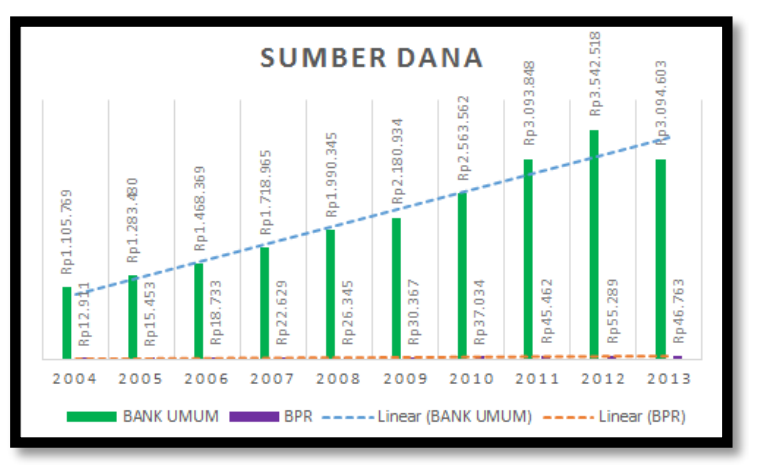

GAMBAR 1.2 PERKEMBANGAN

\section{SUMBER DANA BANK UMUM TAHUN}

2004-2013 DALAM MILLIAR RUPIAH

Sumber: Otoritas Jasa Keuangan (data diolah)

Dari Gambar 1.2 memberikan informasi bahwa indikator sumber dana bank umum dan bank BPR mengalami trend kenaikan dari tahun 2004 sampai tahun 2013 Trend yang sangat kuat pada bank umum. Trend yang sangat kuat pada bank umum menunjukan bahwa perkembangan kepercayaan yang menyimpan dananya pada bank umum memiliki peningkatan yang signifikan dari tahun 2004 sampai 2013. Begitupun dengan BPR menunjukan trend kenaikan dari tahun 2004 sampai 2013 namun dalam perkembangannya jauh berbeda dengan bank umum. Trend kenaikan sumber dana pada BPR menunjukan adanya peningkatan kepercayaan menyimpan dananya pada BPR. Dengan adanya perkembangan sumber dana baik bank umum maupun BPR harus menunjukan memiliki aset yang berkembang pula. Berikut perkembangan jumlah aset bank umum dan BPR dari tahun 2004 sampai 2014 pada Gambar 1.3.

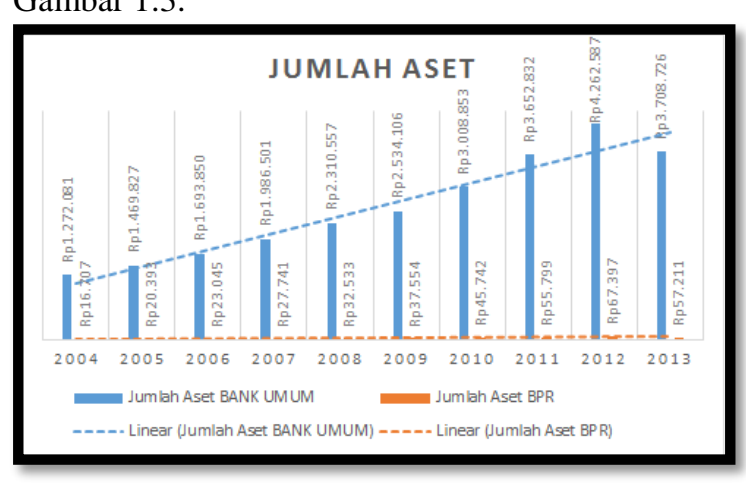

\section{GAMBAR 1.3 PERKEMBANGAN \\ JUMLAH ASET BANK UMUM TAHUN 2004-2013 DALAM MILLIAR RUPIAH}

Sumber: Otoritas Jasa Keuangan (data diolah)

Dari Gambar 1.3 memberikan informasi bahwa jumlah aset bank umum dan bank BPR mengalami trend kenaikan dari tahun 2004 sampai tahun 2013. Trend kenaikan jumlah aset bank umum yang sangat kuat dari tahun 2004 sampai 2013 menunjukan bahwa bank umum berkembang dengan cepat begitupun dengan BPR.

Dari data yang telah diuraikan bahwa perkembangan kegiatan usaha perbankan Indonesia Bank Umum dan Bank Perkreditan Rakyat dari tahun 2004 sampai tahun 2013 cenderung menunjukan trend kenaikan baik dari indikator jumlah penyaluran dana, sumber dana, maupun dari jumlah aset. Pengukuran efisiensi perbankan di Indonesia secara operasional dapat dilihat dari rasio operasional terhadap pendapatan operasional (BOPO). Semakin rendah rasio BOPO menunjukan bahwa bank tersebut sudah melakukan efisiensi dalam mengeluarkan biayabiaya operasionalnya. Berikut gambaran Kinerja perbankan bank umum Indonesia dari tahun 20042013 pada Gambar 1.4 


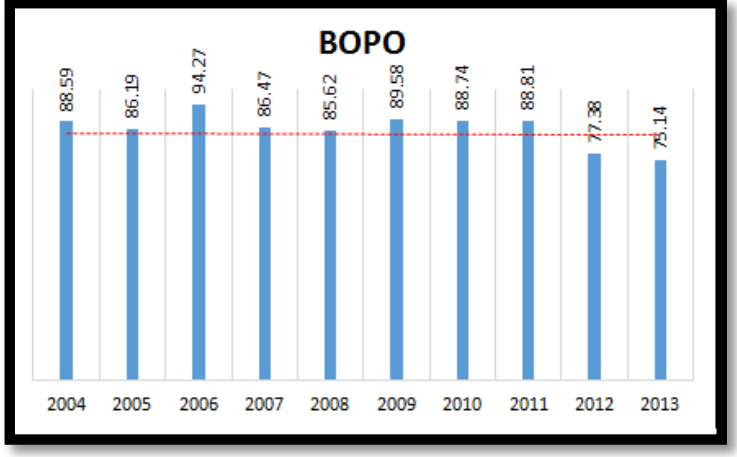

Keterangan : ------ acuan BOPO Bank Indonesia maksimal 85\% Sumber : Otoritas Jasa Keuangan (data diolah)

\section{GAMBAR 1.4 PERKEMBANGAN RASIO BOPO BANK UMUM TAHUN 2004-2013 DALAM PERSEN}

Dari Gambar 1.4 memberikan informasi bahwa kinerja bank umum Indonesia yang tergambar pada rasio BOPO dari tahun 2004 sapai tahun 2013 berfluktuatif. Menurut Bank Indonesia sebagai regulator perbankan Indonesia, memberikan acuan rasio BOPO antara 60 sampai 85 persen. Namun beberapa tahun pada Gambar 1.4 terdapat pencapaian BOPO lebih dari acuan. Hal ini menunjukan bahwa bank umum sedang mengalami inefisiensi dalam penggunaan biaya operasionalnya sehingga diperlukan studi analisis untuk mengukur kinerja efisiensi terhadap perbankan nasional. Karena yang tergolong bank umum itu banyak maka perlunya untuk mengetahui bank mana yang mengalami inefisiensi dengan memilih bank yang rata-rata rasio BOPO nya besar yaitu bank persero. Berikut gambaran kinerja bank persero pada Gambar 1.5.

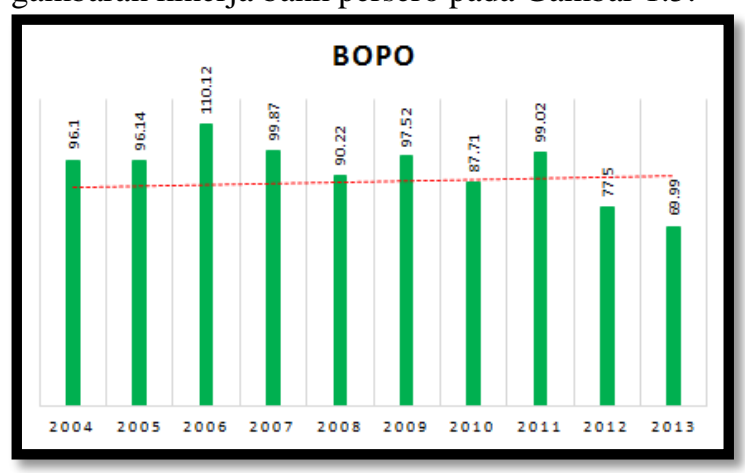

Keterangan : ------ Acuan BOPO Bank Indonesia maksimal 85\% Sumber : Otoritas Jasa Keuangan (data diolah)

GAMBAR 1.5 PERKEMBANGAN RASIO BOPO BANK PERSERO TAHUN 2004-2013 DALAM PERSEN

Dari Gambar 1.5 memberikan informasi bahwa kinerja bank persero yang tergambar pada rasio BOPO dari tahun 2004 sampai 2003 berfluktuatif. Untuk rasio BOPO beberapa tahun menunjukan rasio yang cukup besar dari acuan Bank Indonesia yaitu 60 sampai 85 persen. Maka bank persero sedang mengalami inefisiensi dalam mengelola biaya operasionalnya sehingga harus segera dicarikan solusinya untuk mengetahui input dan output mana yang penggunaannya kurang efisien.

Pada penelitian ini yang menjadi fokus utama yaitu Bank Umun yang tergolong Bank Persero yaitu Bank Mandiri Tbk, Bank Negara Indonesia Tbk, Bank Rakyat Indonesia Tbk, dan Bank Tabungan Negara Tbk. Karena keterbatasan data dan waktu maka penulis memilih Bank Persero untuk dijadikan objek penelitian dengan alasan Bank Persero mengalami inefisiensi.

Pada penelitian ini menggunakan metode perhitungan Data Envelopment analysis (DEA) untuk menghitung tingkat efisiensi yang diperkenalkan pertama kali oleh Charnes, Cooper dan Rhodes (1978). Metode data yang dibuat sebagai alat bantu untuk evaluasi kinerja suatu aktivitas dalam sebuah unit entitas (organisasi). DEA merupakan pendekatan non-parametrik yang sering banyak dipilih dalam banyak penelitian karena beberapa alasan, menurut Aam Slamet Rusydiana (2013:26), menyatakan bahwa : Pendekatan non-parametrik merupakan pendekatan yang modelnya tidak menetapkan syarat-syarat tertentu yaitu parameter populasi yang menjadi induk sample penelitiannya, penggunaan lebih sederhana, dan mudah digunakan karena tidak membutuhkan banyak spesifikasi bentuk fungsi (sehingga kemungkinan kesalahan pembentukan fungsi lebih kecil).

DEA memiliki keunggulan-keunggulan. Menurut Aam Slamet Rusydiana (2013:36), menyatakan bahwa : DEA mempunyai keunggulan yaitu : 1). Bisa menangani banyak input dan output, 2). Tidak butuh asumsi hubungan fungsional antara variabel input dan output, 3). Unit kegiatan ekonomi dibandingkan secara langsung dengan sesamanya, 4). Dapat membentuk garis frontier fungsi efisiensi terbaik atas variabel input-output dari setiap sampelnya, 5). Input dan output dapat memiliki satuan pengukuran yang berbeda.

Peneliti Fadlan Sufian dan Muzafar Shah Habibullah (2010) mendapatkan hasil penelitian bahwa tingkat efisiensi pinjaman dan modal mendapatkan tingkat efisisiensi yang tinggi pada sektor bank di Thailand. Kemudian pada penelitian selanjutnya Fadlan Sufian (2011) menemukan hasil bahwa operasi bank di korea menunjukan hasil konsisten yang tinggi sebelum adanya nilai tambah pada input. DEA 
dikembangkan sebagai model dalam pengukuran tingkat kinerja atau produktivitas dari sekelompok unit organisasi. Pengukuran dilakukan untuk mengetahui kemungkinan-kemungkinan dalam penggunaan sumber daya yang dapat dilakukan untuk menghasilkan output yang optimal. Produktivitas yang dimaksudkan yaitu jumlah dalam penghematan yang dapat dilakukan pada faktor sumber daya (input) tanpa harus mengurangi jumlah Output yang akan dihasilkan atau peningkatan jumlah output yang mungkin dihasilkan tanpa perlu dilakukan penambahan sumber daya. Pengukuran efisiensi dengan menggunakan metode DEA dilakukan dengan mengidentifikasi unit-unit yang digunakan sebagai referensi yang dapat membantu untuk mencari penyebab dan solusi dari adanya inefisiensi.

Meningkatnya Jumlah usaha pada bank Persero kiranya diperlukan untuk mengetahui tingkat efisiensinya. Pengukuran tingkat efisiensi pertama kali diperkenalkan oleh Charnes, Cooper dan Rhodes (1978). Metode data yang dibuat sebagai alat bantu untuk evaluasi kinerja suatu aktivitas dalam sebuah unit entitas (organisasi) yang dikenal dengan metode DATA ENVELOPMENT ANALYSIS (DEA). Pengukuran dilakukan untuk mengetahui kemungkinankemungkinan dalam penggunaan sumber daya yang dapat dilakukan untuk menghasilkan output yang optimal. Produktivitas yang dimaksudkan yaitu jumlah dalam penghematan yang dapat dilakukan pada faktor sumber daya (input) tanpa harus mengurangi jumlah Output yang akan dihasilkan atau peningkatan jumlah output yang mungkin dihasilkan tanpa perlu dilakukan penambahan sumber daya.

Adapun tujuan penelitian ini untuk memperoleh informasi mengenai: 1). Gambaran umum variabel input (Aset, Deposito, dan Beban Personalia) dan variabel output (Kredit, dan Pendapatan Operasional Lainnya) pada Bank Persero Tahun 2004-2013. 2). Efisiensi Teknik Bank Persero dengan Menggunakan Data Envelopment Analysis (DEA) Tahun 2004-2013. 3). Efisiensi skala pada Bank Persero berada pada tahap Decreasing return to scale, Constant return to scale, atau Increasing return to scale.

\section{KAJIAN PUSTAKA}

Menurut Soekrisno (2010:18)
menyatakan bahwa, "aset merupakan manfaat
sumber daya ekonomi di masa akan datang yang
cukup pasti, yang diperoleh atau dikuasai oleh
satu kesatuan usaha, sebagai akibat transaksi di
masa lalu. Sedangkan Menurut IAI dalam SAK

(2009:9), "Aset adalah sumber daya yang dikuasai oleh perusahaan sebagai akibat dari masa lalu dan dari mana manfaat ekonomi dimasa depan diharapkan akan diperoleh perusahaan".

Pengertian Deposito menurut UndangUndang Perbankan Nomor 10 Tahun 1998 adalah simpanan yang penarikannya hanya dapat dilakukan pada waktu tertentu berdasarkan perjanjian nasabah dengan pihak bank. Menurut Kasmir (2010:63), menjelaskan bahwa untuk mencairkan deposito yang dimiliki, deposan dapat menggunakan bilyet deposito atau sertifikat deposito. Dalam praktiknya paling tidak terdapat tiga jenis deposito, yaitu deposito berjangka, sertifikat deposito, dan deposit on call. Masingmasing jenis deposito memiliki kelebihan tersendiri dan khusus deposito berjangka diterbitkan pula dalam mata uang asing.

Menurut Pedoman Akuntansi Perbankan Indonesia (PAPI) buku dua (2008:181) Beban (expenses) adalah penurunan manfaat ekonomi selama suatu periode akuntansi dalam bentuk arus keluar atau penurunan aset atau kenaikan kewajiban yang mengakibatkan penurunan ekuitas yang tidak menyangkut pembagian kepada penanam modal. Sedangkan personalia Personalia adalah serangkaian kegiatan mengelola SDM pada hal-hal yang terkait administratif yang mengatur hubungan industrial antara perusahaan dan karyawannya.

Menurut Kasmir (2011:72) menyatakan bahwa, "kredit berasal dari bahasa Yunani Credere yang berarti kepercayaan atau dalam bahasa Latin Creditum yang berarti kepercayaan akan kebenaran". Rivai (2013:197) menyatakan bahwa, "kredit berasal dari bahasa Latin, Credo, yang berarti I believe, I trust, saya percaya atau saya menaruh kepercayaan. Berdasarkan Undangundang Nomor 10 Tahun 1998, kredit adalah penyediaan uang atau tagihan yang dipersamakan dengan itu, berdasarkan persetujuan atau kesepakatan pinjam meminjam antara bank dengan pihak lain yang diwajibkan pihak peminjam untuk melunasi hutangnya setelah jangka waktu tertentu dengan jumlah bunga.

Menurut Pedoman Akuntansi Perbankan Indonesia buku dua (2008:181) Pendapatan operasional selain bunga adalah semua pendapatan yang diperoleh dari kegiatan yang lazim sebagai usaha bank diluar bunga. Pendapatan operasional lainnya pada perbankan yaitu provisi dan komisi lainnya, penerimaan kembali aset yang telah dihapus bukukan, pendapatan premi asuransi, keuntungan dari aset keuangan yang dimiliki untuk diperdagangkan, keuntungan dari penjualan aset keuangan yang 
diklasifikasikan tersedia untuk dijual, laba bersihneto lain-lain.

Efisiensi dalam suatu perusahaan khususnya perbankan merupakan salah satu parameter kerja yang cukup populer untuk mengukur kinerja bank. Hal ini disebabkan efisiensi yang merupakan jawaban kesulitankesulitan dalam perhitungan ukuran-ukuran kinerja seperti efisiensi teknologi, alokasi, dan efisiensi total Hadad dkk (2003) dalam Maflachatun (2010:44). Rohmana (2009:70) menyatakan bahwa: Efisiensi adalah salah satu masalah pokok dalam ilmu ekonomi. Efisiensi diartikan sebagai tidak adanya barang yang terbuang percuma atau penggunaan sumber daya ekonomi seefektif mungkin untuk memenuhi kebutuhan dan keinginan masyarakat. Secara spesifik, sistem perekonomian dikatakan efisien jika tidak ada satu pun barang tambahan yang diproduksi tanpa mengurangi produksi barang yang lain yaitu selama perekonomian masih berada pada garis batas kemungkinan produksi.

Kemudian menurut Ahmad Syakir Kurnia (2004) dalam Maflachatun (2010:45) menjelaskan bahwa secara keseluruhan efisiensi perbankan dapat didekomposisikan dalam efisiensi skala (scale efficiency), efisiensi cakupan (scope efficiency), efisiensi teknik (technical efficyency), dan efisiensi alokasi (allocative efficiency). Untuk analisis frontier ada dua pendekatan yang dapat digunakan, yaitu pendekatan non-parametrik dan parametrik. Pendekatan parametrik melakukan pengukuran dengan menggunakan ekonometrik yang stokastik dan berusaha menghilangkan gangguan dari pengaruh ketidakefisienan (Nuryana Sari, 2013:20). Metode parametrik meliputi Stochastic Frontier Approach (SFA), Thick Frontier Approach (TFA), dan Distribution Free Approach (SFA). Metode non parametrik dengan program linier (Non parametric Linear Progamming Approach) melakukan pengukuran non parametrik dengan menggunakan pendekatan yang tidak stokastik dan cenderung mengkombinasikan gangguan dan ketidakefisienan. Metode non parametrik meliputi Free Disposal Hull (FDH) dan Data Envelopment Analysis (DEA) (Aam Slamet R, 2013:12).

Perbedaan antara pendekatan parametrik dan non parametrik, prosedur parametrik untuk melihat hubungan antara input dan output diperlukan informasi yang akurat untuk harga input dan variabel eksogen lainnya. Pengetahuan mengenai bentuk fungsi yang tepat dari frontier dan struktur dari an on-sided error (jika digunakan), dan ukuran sampel yang cukup dibutuhkan untuk menghasilkan kesimpulan secara statistika (statistical inferences). Pendekatan non parametrik tidak menggunakan informasi, sehingga sedikit data yang dibutuhkan, lebih sedikit asumsi yang diperlukan dan sampel yang lebih sedikit dapat dipergunakan. Namun demikian, kesimpulan secara statistika tidak dapat diambil jika menggunakan metode non parametrik (Nuryana Sari, 2013:20-21).

Data Envelopment Analysis (DEA) merupakan metode pengukuran efisiensi yang di perkenalkan pertama kali oleh William W. Cooper. Menurut William W. Cooper et al (2011:1) "Data Envelopment Analysis (DEA) is a data-oriented approach for evaluating the performance of a set of peer entities called Decision-Making Units (DMUs), which convert multiple inputs into multiple output".

Muhammad Faza Firdaus dan Muhamad Nadratuzzaman Hosen (2013:172) menjelaskan bahwa Data Envelopment Analysis merupakan metode non-parametrik yang digunakan dalam mengukur tingkat efisiensi suatu Unit Kegiatan Ekonomi (UKE). Dari kedua definisi dapat disimpulkann bahwa DEA merupakan metode yang digunakan untuk mengevaluasi efisiensi dari suatu unit pengambilan keputusan (unit kerja) yang bertanggungjawab menggunakan sejumlah input untuk memperoleh suatu output yang ditargetkan. Ada beberapa pendekatan yang dapat digunakan untuk menjelaskan hubungan input dan output metode DEA ini yaitu pendekatan produksi (production approach), pendekatan intermediasi (intermediation approach) dan pendekatan asset (asset approach) (Aam Slamet R, 2013:26). Pendekatan produksi menganggap lembaga keuangan sebagai produsen dari akun deposito (deposito account) dan kredit (credit accounts) lalu mendifinisikan output sebagai jumlah tenaga kerja, pengeluaran modal pada aset-aset tetap dan material lainnya. Kemudian pendekatan intermediasi memandang sebuah lembaga keuangan sebagai intermidiator yaitu merubah dan mentranfer aset-aset finansial dari unti-unit surplus menjual unit-unit defisit. Dalam hal ini input institusional seperti biaya tenaga kerja, modal, dan pembiayaan bunga pada deposito. Output yang diukur dalam bentuk kredit pinjaman (loans). Sedangkan pendekatan aset memandang sebuah lembaga keuangan sebagai pencipta kredit pinjaman (loans). Pendekatan ini output didefinisikan ke dalam bentuk aset (Nuryana Sari, 2013: 25-26). 


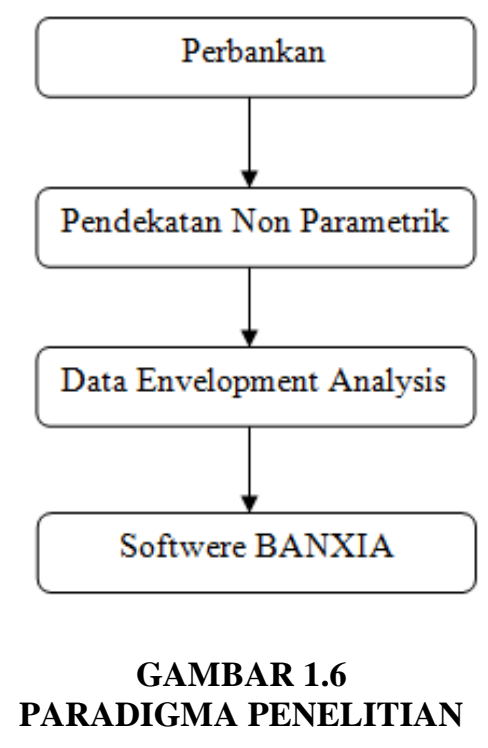

\section{METODE PENELITIAN}

Penelitian ini menganalisis efisiensi teknik bank persero dengan pendekatan intermediasi. Aset, deposito dan beban personalia sebagai faktor input serta Kredit dan pendapatan operasional lainnya sebagai faktor output. Objek penelitian laporan keuangan bank persero yaitu PT. Bank Mandiri Tbk, Bank Negara Indonesia Tbk, Bank Rakyat Indonesia Tbk dan PT. Bank Tabungan Negara Tbk dalam periode waktu 2004-2013. Bank persero yang dipilih karena dalam sepuluh tahun terakhir rasio bopo bank persero menunjukan trend yang tinggi.

Berdasarkan penjelasan tentang objek penelitian yang telah diuraikan, maka akan dianalisis tingkat efisiensi teknik bank persero dengan menggunakan DEA tahun 2004-2013. Penelitian ini dilakukan pada kurung waktu sepuluh tahun, penelitian ini menggunakan metode data envelopment analysis (DEA). Berdasarkan tingkat penjelasan dan bidang penelitian, maka jenis penelitian ini adalah penelitian deskriptif.

\section{HASIL PENELITIAN DAN PEMBAHASAN}

Efisiensi yang dihasilkan dari perhitungan dengan menggunakan metode DEA dengan asumsi CRS dari periode 10 tahun bank persero masih berada dibawah $100 \%$ (inefisien). Untuk bank persero BNI dari periode 10 tahun terdapat 2 tahun yang mencapai $100 \%$ (efisien) dengan rata-rata efisiensi teknis $20 \%$. Kemudian bank Mandiri dalam periode 10 tahun terdapat 2 tahun yang mencapai $100 \%$ (efisien) dengan ratarata efisiensi teknis 20\%. Bank BTN dan bank BRI dalam periode 10 tahun terdapat 4 tahun yang mencapai $100 \%$ (efisien) dengan rata-rata efisiensi teknis berturut-turut $40 \%$ dan $40 \%$ (inefisien).

Efisiensi teknis yang dihasilkan dari perhitungan dengan menggunakan metode DEA dengan asumsi VRS dari periode 10 tahun bank persero masih berada dibawah $100 \%$ (inefisien). Untuk bank persero BNI dari periode 10 tahun terdapat 5 tahun yang mencapai $100 \%$ (efisien) dengan rata-rata efisiensi teknis $50 \%$. Kemudian bank Mandiri dalam periode 10 tahun terdapat 8 tahun yang mencapai $100 \%$ (efisien) dengan ratarata efisiensi teknis $80 \%$. Bank BTN dan bank BRI dalam periode 10 tahun terdapat 4 tahun yang mencapai $100 \%$ (efisien) dengan rata-rata efisiensi teknis berturut-turut $70 \%$ dan $80 \%$ (inefisien).

Efisiensi Skala merupakan perbandingan hasil antara model CRS dengan VRS. Skala relatif bank persero dalam periode 10 tahun belum mencapai skala relatif yang optimum. Secara keseluruhan nilai skala relative masih di bawah 1 dengan perbedaan untuk bank mandiri 0.1505, bank BNI 0.1380, bank BRI 0.0416 dan untuk bank BTN 0.1192. Hal ini menunjukan bahwa bank-bank persero dalam periode 10 tahun belum berada pada efisiensi skala terbaik. Hal ini dikarenakan adanya perbedaan antara hasil perhitungan dengan menggunakan pendekatan CRS dan pendekatan VRS.

\section{KESIMPULAN DAN REKOMENDASI KESIMPULAN}

1. Gambaran umum mengenai variabel input (aset, deposito, dan beban personalia) dan variabel output (kredit dan pendapatan operasional lainnya) bank persero tahun 2004-2013 yaitu sebagai berikut: (1) aset pada bank persero Mandiri rata-rata dalam periode 2004-2013 sebesar 350.809.891 juta rupiah. Bank persero BNI rata-rata sebesar 208.075.363 juta rupiah. Bank persero BRI rata-rata sebesar 253.847.006 juta rupiah dan Bank persero BTN rata-rata sebesar 55.952.221 juta rupiah. (2) deposito bank persero Mandiri rata-rata dalam periode 2004-2013 sebesar 2.220.575 juta rupiah. Bank persero BNI rata-rata sebesar 1.854.713 juta rupiah. Bank persero BRI rata-rata sebesar 3.188.223 juta rupiah dan Bank persero BTN rata-rata sebesar 372.006 juta rupiah. (3) beban personalia bank persero Mandiri rata-rata dalam periode 2004-2013 sebesar 112.386.019 juta rupiah. Bank persero BNI rata-rata sebesar 66.375.128 juta rupiah. Bank persero BRI rata-rata sebesar 81.819.743 juta rupiah dan Bank persero 
BTN rata-rata sebesar 22.599.701 juta rupiah. (4) kredit bank persero Mandiri rata-rata dalam periode 2004-2013 sebesar 180.200.115 juta rupiah. Bank persero BNI rata-rata sebesar 111.472.831 juta rupiah. Bank persero BRI rata-rata sebesar 164.009.605 juta rupiah dan Bank persero BTN rata-rata sebesar 37.529.919 juta rupiah. (5) pendapatan operasional lainnya bank persero Mandiri rata-rata dalam periode 2004-2013 sebesar 112.386.019 juta rupiah. Bank persero BNI rata-rata sebesar 66.375.128 juta rupiah. Bank persero BRI rata-rata sebesar 81.819.743 juta rupiah dan Bank persero BTN rata-rata sebesar 22.599.701 juta rupiah.

2. Hasil analisis efisiensi bank persero tahun 2004-2013 dengan menggunakan metode Data envelopment analysis (DEA) belum mencapai efisiensi optimum. Hal ini dibuktikan dengan hasil analisis menggunakan metode DEA dengan model CRS rata-rata efisiensi teknik bank persero Mandiri sebesar 84,04\%. Kemudian rata-rata efisiensi teknik bank persero BNI sebesar $83,16 \%$, Rata-rata efisiensi teknik bank persero BRI sebesar $94,45 \%$ dan rata-rata efisiensi teknik bank persero BTN sebesar $87,90 \%$. Begitu pun hasil analisis dengan model VRS rata-rata efisiensi teknik bank persero Mandiri sebesar 98,93\%. Kemudian rata-rata efisiensi teknik bank persero $\mathrm{BNI}$ sebesar 96,47\%, Rata-rata efisiensi teknik bank persero BRI sebesar 98,55\% dan ratarata efisiensi teknik bank persero BTN sebesar $99,79 \%$.

3. Efisiensi skala bank-bank persero berdasarkan pendekatan frontier nonparametrik dengan metode DEA (Data Envelopment Analysis) berada pada kondisi skala usaha yang menurun (Decreasing Return to Scale). Hal ini dibuktikan dengan tingkat skala relatif bank persero MANDIRI sebesar 0.8495, BNI sebesar 0.8620, BRI sebesar 0.9584 dan BTN sebesar 0.8808.

\section{REKOMENDASI}

1. Penerapan dimensi gaya hidup yang dilakukan oleh smartphone Samsung Kinerja efisiensi Bank Persero periode 2004-2013 belum seluruhnya efisien. Hal ini dapat disebabkan salah satunya karena dalam 10 tahun terakhir bank membuka beberapa cabang banknya sehingga beban personalia biayanya meningkat dibuktikan dengan perhitungan DEA menunjukan beban personalia harus banyak dikurangi agar menjadi efisien. Salah satu cara untuk mencapai efisiensi yang optimum maka dalam 10 tahun ke depan harus mempertimbangkan penambahan tenaga kerja baru dan pembukaan cabang bank baru dengan penuh perhitungan.

2. Perhitungan efisiensi dengan menggunakan metode DEA masih memiliki kekurangan, baik dalam memilih pendekatan maupun pemilihan variabel input dan outputnya dalam industri finansial oleh karena itu penelitian selanjutnya diharapkan menggunakan metode lain untuk memperkaya ilmu pengetahuan khususnya dalam menghitung efisiensi dengan mengunakan DEA.

\section{DAFTAR PUSTAKA}

Ahman, Eeng \& Rohmana, Yana. (2007). Pengantar Teori Ekonomi Mikro. Laboratorium Ekonomi dan Koperasi. Bandung.

Arikunto, Suharsimi.2009. Prosedur Penelitian Suatu pendekatan praktek. Jakarta: Rineka Cipta.

Chang Won Lee, N.K. Kwak, Walter A. Garrett.2013. A Comparative Appraisal of Operational Efficiency in U.S. Research-University Libraries: A DEA Approach, in Kenneth D. Lawrence, Gary Kleinman (ed.) Applications of Management Science (Applications of Management Science, Volume 16), Emerald Group Publishing Limited, pp.117-130.

Charnes, A., et. Al.1981. Evaluating Program and Managerial Efficiency: An Application of Data Envelopment Analysis to Program Follow Through Management Science Vol. 27, No. 6.

Farhana Ismail, M. Shabri Abd. Majid, Rossazana Ab. Rahim,.2013. Efficiency of Islamic and conventional banks in Malaysia, Journal of Financial Reporting and Accounting, Vol. 11 Iss: 1, pp.92 - 107.

Firdaus, M. F., \& Hosen, M. N. 2013. Efisiensi Bank Umum Syariah Menggunakan Pendekatan Two-Stage Data Envelopment Analysis. Buletin Ekonomi Moneter Dan Perbankan, 186, 167

Ikatan Akuntan Indonesia.2009. Standar Akuntansi Keuangan, Salemba Empat Jakarta

Ioannis E. Tsolas.2011. Bank branch-level DEA to assess overall efficiency, EuroMed Journal of Business, Vol. 6 Iss: 3, pp.359 -377 . 
Kasmir, 2010. Bank dan Lembaga Keuangan Lainnya. Jakarta: Raja Graffindo Pers

Rivai, Veithzal dkk.2013. Commercial Bank Management : Manajemen Perbankan Dari Teori Ke Praktik.Jakarta:Rajawali Pers.

Rusydiana, Aam Slamet dan Tim Smart Consulting.2013. Mengukur Tingkat Efisiensi dengan Data Envelopment Analysis (DEA) : Teori dan Aplikasi.Bogor: Smart Consulting.

Mohamed Hisham Yahya, Junaina Muhammad, Abdul Razak Abdul Hadi.2012. "A comparative study on the level of efficiency between Islamic and conventional banking systems in Malaysia", International Journal of Islamic and Middle Eastern Finance and Management, Vol. 5 Iss: 1, pp.48 - 62.

Nafis Alam, 2013. Impact of banking regulation on risk and efficiency in Islamic banking, Journal of Financial Reporting and Accounting, Vol. 11 Iss: 1, pp.29-50.

Sufian, Fadzlan.2011. Benchmarking the efficiency of the Korean banking sector: a DEA approach, Benchmarking: An International Journal, Vol. 18 Iss: 1, pp. $107-127$.

Sufian, Fadzlan Muzafar Shah Habibullah.2010. Developments in the efficiency of the Thailand banking sector: a DEA approach, International Journal of Development Issues, Vol. 9 Iss: 3, pp. $226-245$.

Sugiyono.2013. Metode Penelitian Kuantitatif, kualitatif dan $R \&$ \& $D$. Bandung: Alfabeta.

Sugiyono.2011. Metode Penelitian Kuantitatif, kualitatif dan $R \& D$. Bandung: Alfabeta.

Sugiyono.2011. Metode Penelitian Kuantitatif, kualitatif dan R \& D. Bandung: Alfabeta.

Sukrisno, Agoes dan Estralita Trisnawati. 2010. Akuntansi Perpajakan Edisi 2 Revisi. Jakarta : salemba empat

Tamer Mohamed Shahwan, Yousef Mohammed Hassan.2013. Efficiency analysis of UAE banks using data envelopment analysis, Journal of Economic and Administrative Sciences, Vol. 29 Iss: 1, pp.4-20.

Tim Perumus PAPI. 2008. Pedoman Akuntansi Perbankan Indonesia, Bank Indonesia dan Ikatan Akuntansi Indonesia ( IAI ), Jakarta

W.W. Cooper et al. 2011. Handbook on Data Envelopment Analysis, International Series in Operations Researh \& Management Science 164, DOI
10.1007/978-1-4419-6151-8_1, Spinger science+business media, LLC 2011

Skripsi

Uctavia, Uma.2013. Analisis tingkat efisiensi Bank Umum Syariah (BUS) dan Unit Usaha Syariah (UUS) Di Indonesia Dengan Menggunakan Metode Data Envelopment Analysis (DEA) periode 2007-2011. Universitas Diponogoro Semarang.

Sari, Nuryana.2010. Analisis Tingkat Efisiensi Perbankan Syariah Dan Faktor Internal Eksternal Yang Mempengaruhinya.Universitas Negeri Islam Syarif Hidayatullah.

Maflachatun.2010. Analisis Efisiensi Teknis Perbankan Syariah di Indonesia Dengan Menggunakan Metode Data Envelopment Analysis (DEA). Universitas Diponogoro Semarang

Maesaroh, Imas.2014. Analisis Efisiensi Ekonomi Dalam Penggunaan Faktor-faktor Produksi Dengan Metode Data Envelopment Analysis (DEA).Universitas Pendidikan Indonesia 